\title{
硫酸化アルギン酸電解質膜の圧力こう配による溶媒透過挙動
}

$$
\begin{aligned}
& \text { 勝野能* 葛西裕 }{ }^{* *} \text { 森田秀 幸* } \\
& \text { 堀 中 順 一* 浦 山健 治 }{ }^{* *} \text { 㴰川敏 算 }{ }^{* * *}
\end{aligned}
$$

\section{Solvent Permeation Behavior of Alginate Sulfate Electrolyte Membranes under Pressure Gradient}

\author{
by \\ Chikara Katsuno *, Yutaka KaSAI ${ }^{* *}$, Hideyuki Morita *, Junichi HorinaKA ${ }^{*}$, \\ Kenji Urayama $^{* * *}$ and Toshikazu Takigawa ${ }^{* * *}$
}

\begin{abstract}
We have investigated the flow rate of methanol aqueous solutions through alginate sulfate (AS) electrolyte membranes under a constant pressure gradient. The solvent flow rate for the AS membranes with low cross-linking densities is considerably higher than that of alginic acid membrane when the methanol fraction $(\phi)$ is low. The solvent flow rate drastically decreases as $\phi$ increases, and no solvent permeation is observed when $\phi>0.6$. This strong $\phi$ dependence of flow rate is not simply explained by the $\phi$ dependence of swelling degree $(\Theta)$, because the reduction in $\Theta$ by increasing $\phi$ is considerably small. The confocal microscopy reveals a higher order network structure with a mesh size of ca. $10 \mu \mathrm{m}$ in the water-swollen AS membrane. The network structure results from the phase separation of the hydrophilic and hydrophobic domains. The hydrophilic and hydrophobic domains are mainly composed of the sulfated blocks and non-sulfated blocks, respectively. The mesh size of the network structure becomes considerably smaller as $\phi$ increases. The solvent permeability of the AS membranes is mainly controlled by the mesh size of the higher order network structure.
\end{abstract}

Key words : Alginate sulfate, Permeation behavior, Confocal laser scanning microscopy, Swelling, Electrolyte membrane

\section{1 緒言}

アルギン酸はコンブやワカメなど褐藻類の細胞間粘質 多糖であり， $\beta-1,4$ 結合した $\beta-\mathrm{D}$-マンヌロン酸からなる $\mathrm{M}$ ブロック， $\alpha-1,4$ 結合した $\alpha-\mathrm{L}-$ グルロン酸からなる $\mathrm{G}$ ブロック，およびマンヌロン酸とグルロン酸が交互に結合 した MG ブロックによって構成されている (Fig. 1).1) 3) アルギン酸およびその塩は工業的には, 食品の増粘安定 剂やゲル化剂, 柬科印象剂, 飼料の粘結剂, 化粧品原料, 繊維用捺染糊剤などの用途に利用されている。アルギン 酸はカルシウムイオンなどの 2 価の陽イオンの存在下で

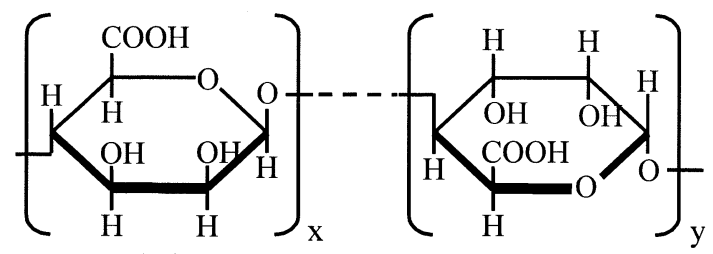

(M)

(G)

Fig. 1 Structure of (M) $\beta-\mathrm{D}-$ mannuroic acid and (G) $\alpha-\mathrm{L}-$ guluronic acid units of alginic acid.
ゲル化する ${ }^{4)}$ が，酸性条件下においてはカルボキシ基間 の水素結合によってアルギン酸単独で物理ゲルを形成す る5)ことが知られている。 そのため, アルギン酸をキャスト 法等により製膜後, 酸溶液に浸漬しゲル化させることに より水に不溶な電解質膜を作製することが可能である。著 者らはアルギン酸誘導体の 1 種である硫酸化アルギン酸か ら電解質膜を作製し, 直接メタノール形燃料電池 (DMFC) 用電解質膜としての特性の評価を行った。․ ${ }^{6} \mathrm{DMFC}$ 用電解 質膜には起電力低下をもたらす膜のメタノール透過を抑 制することが求められている。著者らは，硫酸化アルギ ン酸電解質膜の濃度勾配下のメタノール透過性を評価し, DMFC 用の一般的な電解質膜である Nafion ${ }^{\circledR} 112$ より も高メタノール濃度においてメタノール透過抑制が優れ ていることを示した6. 燃料のメタノールがポンプ圧によ り供給される DMFCでは, 電解質膜は圧力勾配下にお かれることになる。このため, 圧力公配下での膜のメタ ノール透過を調べることは, DMFC 用の電解質膜への応 用に関して重要である。アルギン酸膜の溶媒透過挙動に ついてはパーベーパレーション法7) 11) や圧力勾配 ${ }^{11)}$ よる溶媒透過挙動の報告がある。しかし，アルギン酸誘

* 京都大学大学院工学研究科材料化学専攻 ７615-8510 京都市西京区京都大学桂, Dept. of Mat. Chem., Kyoto Univ., Nishikyo-ku, Kyoto, 615-8510

** 青森県産業技術センター工業総合研究所 ＝030-0113 青森市第二問屋町, Ind. Res. Inst., Aomori Pref. Ind. Tech. Res. Center, Dainitonya-machi, Aomori, 030-0133

*** 正 会員 京都大学大学院工学研究科材料化学専攻 ₹615-8510 京都市西京区京都大学桂, Dept. of Mat. Chem., Kyoto Univ., Nishikyo-ku, Kyoto, 615-8510 
導体の電解質膜の溶媒透過挙動, 特に圧力勾配下の挙動 に関しての報告はほとんど行われていない.

本研究は硫酸化アルギン酸電解質膜に関して種々のメ タノール分率のメタノール水溶液に対する圧力勾配下で の透過速度を調べた．さらに，共焦点レーザー顕微鏡に より膨潤膜の観察を行い, 膜の高次構造と溶媒透過特性 の相関について考察した.

\section{2 実}

\section{験}

\section{$2 \cdot 1$ 試薬}

アルギン酸ナトリウム $(\mathrm{AANa})$, ジメチルスルホキシ ド $(\mathrm{DMSO})$, および三酸化硫黄ピリジン錯体 $\left(\mathrm{SO}_{3} \cdot \mathrm{Py}\right)$ は和光純薬工業(株)から購入したものをそのまま用いた。 その他の試薬は市販特級品を用いた。

\section{$\mathbf{2} \cdot \mathbf{2}$ 試料}

$\mathrm{AANa}$ の硫酸化はプルランの硫酸化の方法 ${ }^{12)}$ を参考に して行った. DMSO に AANa を $2 \mathrm{~g}$ と所定量の $\mathrm{SO}_{3} \cdot \mathrm{Py}$ を 加え, かくはんしながら $40^{\circ} \mathrm{C}$ で 5 時間硫酸化反応を行っ た. AANaの構成単糖に対する $\mathrm{SO}_{3}$. $\mathrm{Py}$ のモル比は 2 2.5 まで変化させた。得られた反応混合物にエタノールを 加え，析出した沈殿物をろ別した。この沈殿物を蒸留水 に加え，水酸化ナトリウム水溶液で中和し溶解させた後， 3 日以上透析を行い, 凍結乾燥することにより硫酸化ア ルギン酸ナトリウム $(\mathrm{ASNa})$ を得た。

電解質膜はキャスト法により作製した。ASNaの約 $2 \mathrm{wt} \%$ 水溶液をシャーレに流し込み, 室温にて 1 日以上乾 燥することにより電解質膜を得た。この膜を $0.5 \mathrm{~N}$ 塩酸 溶液に 2 時間浸漬しナトリウムイオンを水素イオンにイ オン交換することにより硫酸化アルギン酸 (AS) 電解質 膜を作製した。得られた膜は蒸留水で十分洗浄し試験に 供した. Table 1 に示すように仕込み時の $\mathrm{SO}_{3} \cdot \mathrm{Py}$ 量の 異なる 3 種の AS 電解質膜（AS-1, AS-2，打よび AS-3） を作製した。

\section{$2 \cdot 3$ 測定}

電解質膜に含まれる硫黄の含量を(粈島津製作所製蛍光 $\mathrm{X}$ 線分析装置 (EDX-800HS2) を用いて管電圧 $15 \mathrm{kV}$ にて 測定した。

電解質膜のイオン交換容量 (IEC ; mequiv $\mathrm{g}^{-1}$ ) は滴定 法により測定した。電解質膜を飽和塭化ナトリウム水溶 液に少なくとも 2 時間以上浸漬し, 膜の水素イオンをナ トリウムイオンに置換した。この溶液をフェノールフタ

Table 1 Molar ratio of $\mathrm{SO}_{3} \cdot \mathrm{Py}, \mathrm{DS}$, and IEC of the membraness.

\begin{tabular}{lccc}
\hline Sample & $\begin{array}{c}\text { Molar ratio of } \\
\mathrm{SO}_{3} \cdot \mathrm{Py}\end{array}$ & $\mathrm{DS}^{\mathrm{a})}$ & $\begin{array}{c}\mathrm{IEC}^{\mathrm{b})}, \\
\text { mequiv } \mathrm{g}^{-1}\end{array}$ \\
\hline $\mathrm{AA}$ & - & 0.00 & 1.7 \\
\hline $\mathrm{AS}-1$ & 2.0 & 0.15 & 2.6 \\
$\mathrm{AS}-2$ & 2.3 & $0.15^{\mathrm{c})}$ & 3.0 \\
$\mathrm{AS}-3$ & 2.5 & 0.14 & 3.6 \\
\hline
\end{tabular}

a) The degree of substitution of hydroxyl groups with sulfate groups per component monosaccharide calculated from sulfur content. ${ }^{\text {b) }}$ Ion exchange capacity determined by titration method. ${ }^{\text {c) }}$ Estimated by extrapolation.
レインを指示薬として $0.02 \mathrm{~N}$ 水酸化ナトリウム水溶液に て滴定した. IEC は乾燥膜重量当りの交換基のミリモル 当量で表した。

含水状態の電解質膜をメタノールの重量分率 $(\phi)$ の異 なるメタノール水溶液に浸漬することにより，混合溶媒 に対する膨潤度 $(\Theta)$ を次式を用いて算出した.

$$
\Theta=\frac{m_{\mathrm{S}}}{m_{\mathrm{M}}}
$$

ここで $m_{\mathrm{S}}$ と $m_{\mathrm{M}}$ はそれぞれ膨潤膜中の溶媒の重量と乾 燥膜の重量である。

溶媒透過測定は自作の透過流量測定装置 (Fig. 2) を用 いて行った。膜をシリコンゴムとメッシュで挟み，金属 製器具を用いて固定した。ポンプを用いて $0.1 \mathrm{MPa} の 一$ 定圧力を印加することにより溶媒を透過させ，透過流量

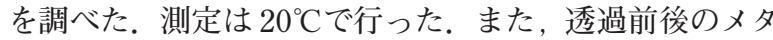
ノール水溶液のメタノールの重量分率を熱伝導検出器を 備えた(株)島津製作所製ガスクロマトグラフ GC-14B を用 いて測定した。

共焦点レーザー顕微鏡観察は(株)キーエンス製 VK-9500 を用いてレーザー波長 $408 \mathrm{~nm}$ ，反射モードにて行った。

\section{$3 \cdot 1$ 電解質膜の膨潤度}

\section{3 結果および考察}

蛍光 X 線分析により各 AS 膜に含まれる硫黄の量を測 定し，含まれる硫黄の量からアルギン酸の構成単糖当り の硫酸基の置換度 (DS) を求めた。各膜の DS と IEC を Table 1 に示す。各 AS 膜の DS はほぼ等しく，IEC は $\mathrm{SO}_{3} \cdot \mathrm{Py}$ のモル比に応じて増加した。 アルギン酸 (AA) 膜 および各 AS 膜のメタノール水溶液に対する $\Theta$ の 依存 性を Fig. 3 に示す. AS 膜はAA 膜よりも $\Theta$ が非常に高 く, 各 AS 膜を比較すると IEC の高い AS 膜ほど高い $\Theta$ を示した。アルギン酸は $\beta-\mathrm{D}-$ マンヌロン酸からなる $\mathrm{M}$ ブロックと $\alpha-\mathrm{L}-$ グルロン酸からなる $\mathrm{G}$ ブロック，およ びマンヌロン酸とグルロン酸が交互に結合した MG ブ ロックによって構成されており (Fig. 1)，カルボキシ基 間の水素結合による物理架橋が形成されゲル化する. Draget らはグルロン酸とマンヌロン酸の組成の異なる一 連のアルギン酸ゲルの性質を調ベ，グルロン酸が連続した G ブロック部が主に架橋点を形成すること，および安定

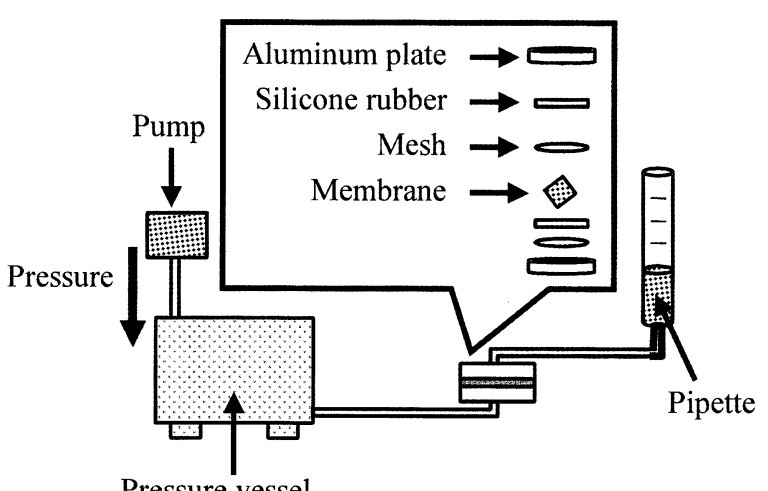

Pressure vessel

Fig. 2 Schematic diagram of solvent permeability measurement. 
な架橋点が形成されるためにはグルロン酸が多数連続し た大きな G ブロックが必要であることを報告している. ${ }^{13)}$ アルギン酸に硫酸化反応を行うことでグルロン酸部位に も硫酸基が導入されることにより安定な架橋点の形成の ために必要なグルロン酸の連続性が失われ，架橋の形成 が妨げられる．また，酸性条件ではアルギン酸の分解が 生じること ${ }^{14)}$ および分子量の低いアルギン酸ほどゲル化 能が低下すること ${ }^{15)}$ から, 高モル比の $\mathrm{SO}_{3} \cdot \mathrm{Py}$ の硫酸化 反応での AS 膜は分子量の低下により架橋の形成が妨げ られることが考えられる。従って, AS 膜が AA膜よりも $\Theta$ が高かったのは，硫酸基が導入されることによる親水 性の増加の効果とこの架橋が減少する効果のためである と考えられる。また，アルギン酸ではカルボキシ基が架 橋点を形成するため, 架橋の形成に関与していないカル ボキシ基が多く存在する膜ほど IEC が高くなる。すなわ ち架橋密度の低い膜ほど IEC 值が高い. IEC 值にはイオ ン交換基の量が反映される，イオン交換基は，AA膜では カルボキシ基のみであるが AS 膜ではカルボキシ基だけで なく導入された硫酸基も含まれる。このため, DSが同じ AS 膜では IEC の高い膜が高い膨潤度を示す．Fig. 3 にお いて AA，AS-3 ともに $\phi$ が増大するにつれて $\Theta$ が減少す るが，その減少率は AS-3 のほうが大きく, 両膜間のメタ ノールに対する親溶媒性の差は純水に比べ小さいことが わかった。

\section{$3 \cdot 2$ 電解質膜の溶媒透過挙動}

AS-3 膜の圧力下の透過溶媒の積算流量の時間依存性を Fig. 4 に示す. 積算流量は時間の増加とともにほぼ単調 に増加し，その曲線の傾きは長時間ではほぼ一定となり 定常状態に達する．直線部分の傾きから次式により定常 状態での流束 $J_{\mathrm{V}}$ を求めた.

$$
J_{\mathrm{V}}=\frac{\mathrm{d} v}{\mathrm{~d} t} \frac{1}{a}
$$

ここで, $a$ は膜の有効表面積, $t$ は時間, $v$ は積算流量で ある、AA，AS-1，执よ゙ AS-2 の各膜に対しても同様に $J_{\mathrm{V}}$ を求めた。試料間での膜厚の違いの影響を除くため $J_{\mathrm{V}}$ に膜厚 $(d)$ を乗じた $J_{\mathrm{v}} d$ と $\phi$ との関係を Fig. 5 に示す.

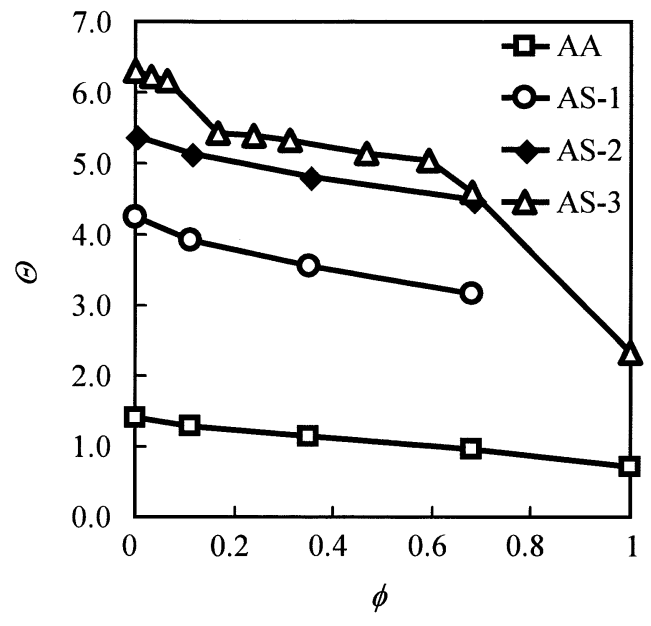

Fig. 3 Methanol fraction dependence of degree of swelling for the membranes.

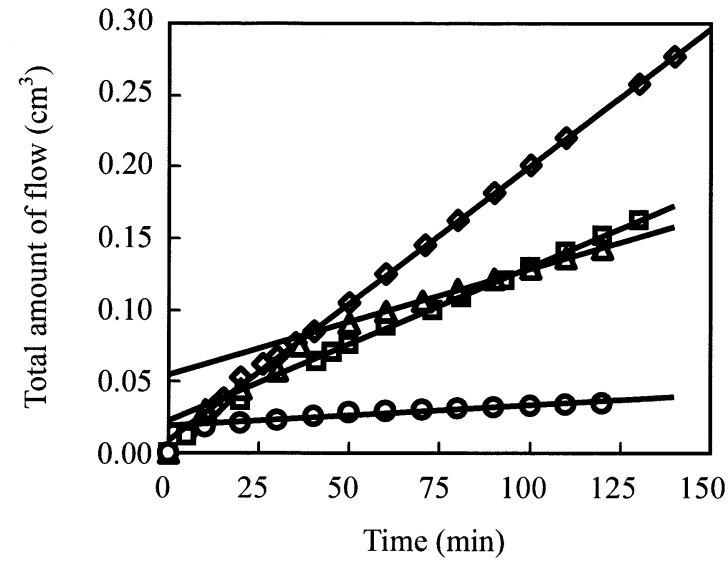

Fig. 4 Time dependence of total amount of solvent flow for AS-3: $\diamond, \phi=0.032 ; \square, \phi=0.17 ; \triangle, \phi=$ $0.31 ; \bigcirc, \phi=0.59$

$\phi=0$ (蒸留水) での各膜の $J_{\mathrm{V}} d$ を比較すると, AS 膜は $\mathrm{AA}$ 膜よりも $J_{\mathrm{v}} d$ が高く, AS 膜の中では IEC の高い膜す なわち架橋密度が低い膜ほど高い $J_{\mathrm{v}} d$ を示した。 $\phi=0$ で の各 AS 膜の透過速度と膨潤度の比較を Fig. 6 に示す. IEC に対する $J_{\mathrm{V}} d$ の増加率は $\Theta$ の増加率に比べ非常に大

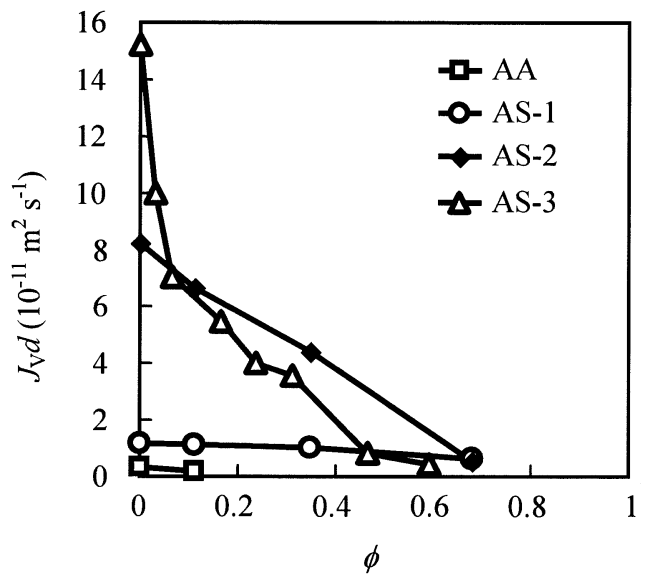

Fig. 5 Methanol fraction dependence of flow rate for the membranes.

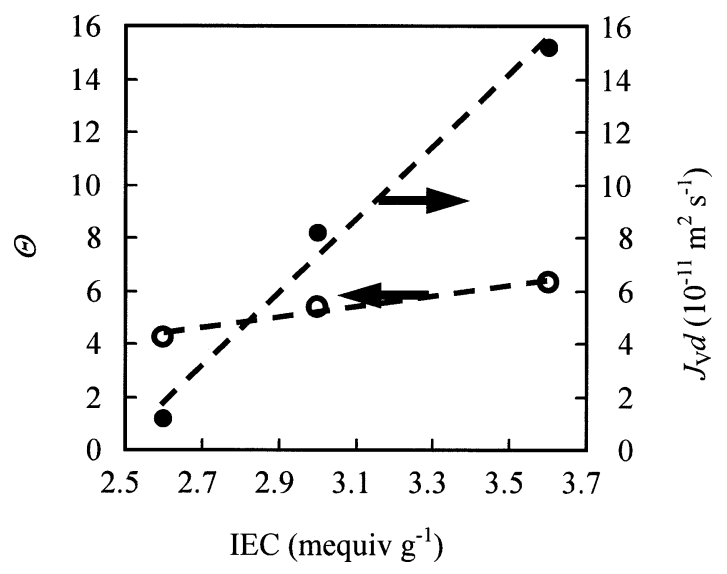

Fig. 6 IEC dependence of degree of swelling and flow rate for the AS membranes at $\phi=0: \bigcirc$, degree of swelling; , flow rate. 
きいことがわかる。 また, Fig. 5 よりどの AS 膜も $J_{\mathrm{v}} d$ は $\phi$ の増加とともに減少することがわかる。特に, 最も架 橋密度の低い AS-3 の $J_{\mathrm{V}} d$ の $\phi$ 依存性は非常に大きく， $J_{\mathrm{v}} d$ は $\phi$ の増加とともに急激に減少し $\phi=0.6$ 以上ではゼ 口となり溶媒透過は観察されなくなった。 Fig. 7 にAS-3 の $\Theta$ 扎よび $J_{\mathrm{v}} d$ の $\phi$ 依存性の比較を示す。 $\Theta$ の $\phi$ 依存性 は小さく，溶媒透過がほぼ起こらなくなる $\phi=0.6$ にお いても $\Theta$ は $\phi=0$ に比べ $20 \%$ 程度の減少に留まってい る。ポリ（N-イソプロピルアクリルアミド）のような中 性ゲル膜の N, N-ジメチルホルムアミド水溶液の溶媒透 過挙動では， $\Theta$ と $J_{\mathrm{V}}$ は同様の溶媒組成依存性を示し， $J_{\mathrm{V}}$ の増加は $\Theta$ の増加すなわちゲル網目サイズの増加によっ て説明できることが報告されている. ${ }^{16)}$ しかし， AS-3の $J \mathrm{~V}$ は $\Theta$ に比べて $\phi$ 依存性が著しく大きく, $\Theta$ から単純に推 測されるゲル網目サイズの変化では説明できない．この 点については次節であらためて考察する。

Fig. 8 に AS-3 に関するメタノール水溶液の膜透過前 後の組成の関係を示す．罒中の傾き 1 の破線は透過前後 で溶液の組成に変化がない場合に相当する， $\phi_{\text {out }}$ の值は 破線に近く, 静水圧下での透過によりメタノール水溶液

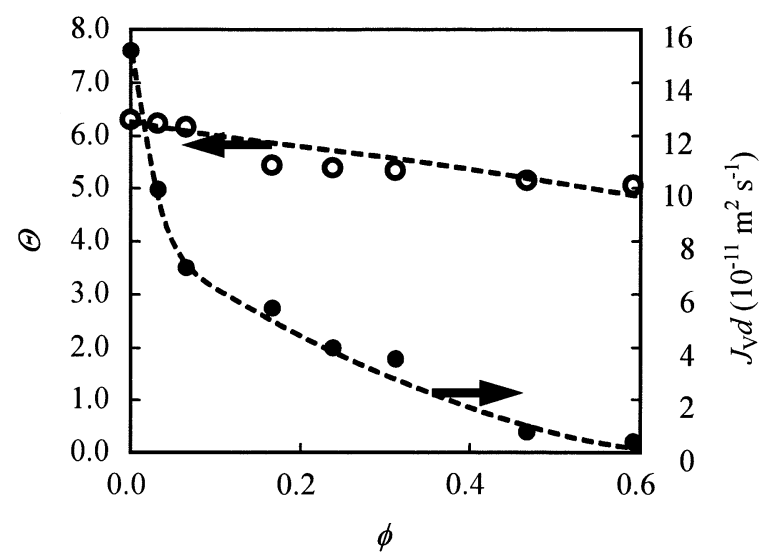

Fig. 7 Methanol fraction dependence of degree of swelling and flow rate for AS-3: $\bigcirc$, degree of swelling; $\mathbf{O}$, flow rate.

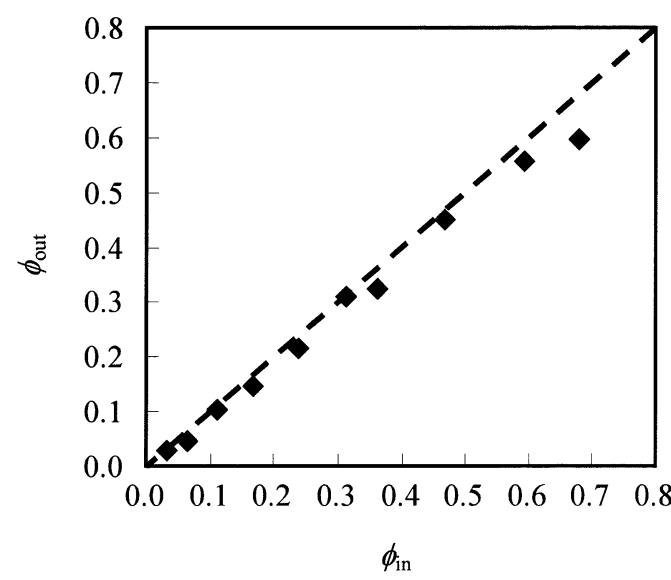

Fig. 8 Methanol fraction of the downstream solvent as a function of methanol fraction of the upstream solvent for AS-3. The slope of the dashed line is unity.
の組成の変化はほとんど生じていない. AS 膜は静水圧下 ではメタノールの選択的分離を示さないことがわかる. AA 膜を用いた場合も透過前後で溶液の組成にほとんど 変化がないことが報告されている.11)

\section{$3 \cdot 3$ 電解質膜の構造}

蒸留水 $(\phi=0)$ にて膨潤した AA 膜, AS-1，およびAS-3 膜の共焦点レーザー顕微鏡による観察画像を Fig. 9 (a) (c)に示す．Hirokawa らはポリ（N-イソプロピルアクリ ルアミド）ゲルの相分離構造の観察を共焦点レーザー顕 微鏡を用いて行い，反射モードによって得られた画像に打 いて明部はポリマーネットワークが浱厚な領域であり，暗 部はポリマーネットワークが希薄な領域であることを報告 している. ${ }^{17}$ 架橋密度が低い AS-3 の水膨潤膜 (Fig. 9 (c)) では明部と暗部が明確に分離したメッシュサイズが $10 \mu \mathrm{m}$ 程度の網目状構造が観察された。 AS-3 よりも架橋密度が 高い AS-1 の水膨潤膜 (Fig. 9 (b)) に扑いても AS-3 ほど明 確ではないが同様の網目状構造が観察された。一方，AA の水膨潤膜 (Fig. 9 (a))ではこのような網目状構造は観察 されなかった。これらのことから，ASの水膨潤膜は水分 の少ないドメインを骨格とする網目構造体であり, 架橋 密度の低い AS 膜はメッシュサイズがマイクロメートル オーダーになることがわかる。 メタノール水溶液（ $\phi=$

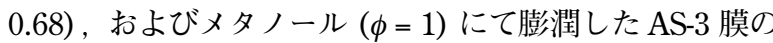
観察画像を Fig. 9 (d)，(e)にそれでれ示す。AS-3 膜の網 目状構造はメタノール分率が増加するにつれて明瞭でな くなり $\phi=1$ では観察されなくなることから, 網目構造 体のメッシュサイズが $\phi$ の増加とともに小さくなること がわかる。また， AA 膜では溶媒組成による構造の違い はみられなかった。

AS-3 の水膨潤膜でみられた網目状構造 (Fig. 9 (c))に ついて考察する．前に述べたように，アルギン酸ゲルの 架橋点はグルロン酸が連続した G ブロック部で主に形成 され，安定な架橋点が形成されるためにはグルロン酸が 多数連続した大きな G ブロック部が必要である.13)グルロ ン酸部位に硫酸基が導入されると $\mathrm{G}$ ブロックの連続性は 失われる。従って AS 膜では, 硫酸化されていない G ブ ロック部に架橋は局在化する傾向があると考えられる。こ のため AS 膜では，硫酸化されている AA ブロック (SAA）を多く含むドメイン（S-AA リッチドメイン）と硫酸 化されていない AA ブロック (G-AA) を多く含むドメイ ン（G-AAリッチドメイン）とは架橋密度が大きく異なっ ている。架橋密度が低く親水性の高い S-AA リッチドメイ ンは, 架橋密度が高く親水性の低い G-AA リッチドメイン よりも水中では大きく膨潤する. AS-3 の水膨潤膜は, S-AA リッチドメインと G-AA リッチドメインからなる共連続な 二相構造をとるものと考えられる. AS-3 のメタノール膨潤 膜では, 明確な相分離構造は見られなかった (Fig. 9 (e)). これは S-AA リッチドメインと G-AA リッチドメイン間の メタノールに対する親溶媒性の差が小さく, 両ドメイン 間の密度（膨潤度）の差がほとんどなくなるためである。

AS-3 の溶媒透過挙動の $\phi$ 依存性 (Fig. 7) は, 同膜の 高次構造の $\phi$ 依存性（Fig. 9 (c) (e)）によって定性的 

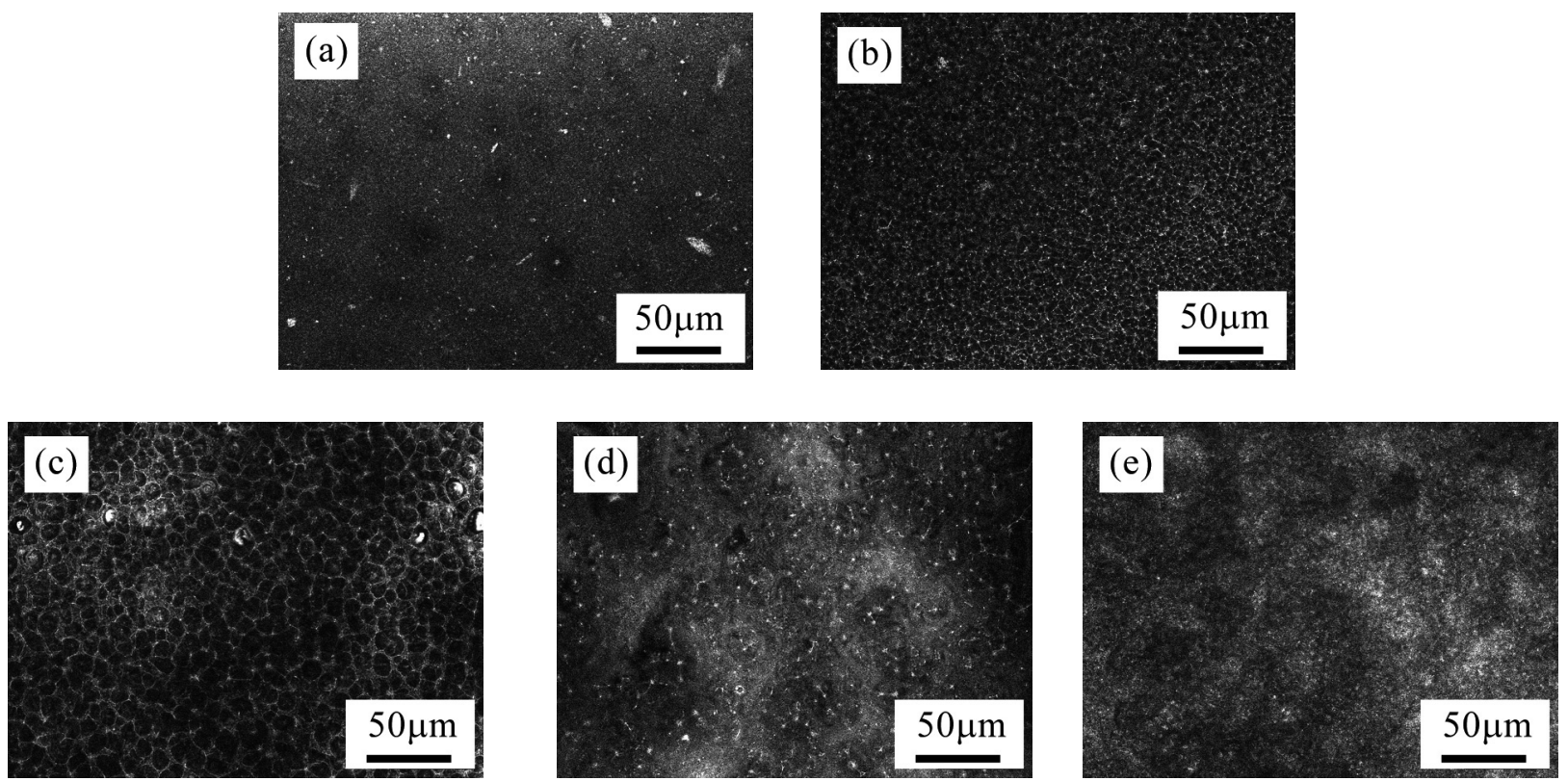

Fig. 9 Confocal laser scanning microscope images of (a) AA, (b) AS-1, and (c) AS-3 membranes swollen in distilled water $(\phi=0)$; (d) AS-3 membrane swollen in methanol aqueous solution $(\phi=0.68)$; (e) AS-3 membrane swollen in methanol $(\phi=1)$.

に説明できるＡS-3 のような架橋密度の低い AS 膜では， 蒸留水中においては S-AA リッチドメインが大きく膨潤 し, 網目状相分離構造の大きな網目部分の親水性領域を 溶媒が流路として透過するため透過速度は大きい. 一方， メタノール中では膜中の粗密差がなくなり流路が形成さ れなくなるため溶媒の透過は妨げられる。AS膜ではマク ロな膨潤度よりも網目状高次構造のメッシュサイズの方 が強い $\phi$ 依存性をもち, 溶媒透過性の支配因子として作 用している。

\section{4 結 言}

低架橋密度の硫酸化アルギン酸 (AS) 膜の圧力勾配下 の溶媒透過速度は，アルギン酸膜と比較して低メタノー ル濃度では非常に高かったが，メタノールの重量分率 $(\phi)$ が増加するにつれ急激に減少し $\phi=0.6$ 以上では溶媒透 過が起こらなくなった。一方，同膜の膨潤度の $\phi$ 依存性は 非常に小さく, 中性ゲルにみられるような溶媒透過速度と 膨潤度の単純な相関関係はみられなかった。共焦点レー ザー顕微鏡による観察の結果，AS 膜の水膨潤状態では 網目状の高次構造が観察された。この網目状の高次構造 は主に S-AA リッチドメインから形成される架橋密度が 低く親水性が高い領域（ポリマーネットワークが希薄な 領域）と，主に G-AA リッチドメインから形成される架 橋密度が高く親水性が低い領域（ポリマーネットワーク が濃厚な領域）からなる二相の共連続構造であると考え られる．高次構造の網目サイズは， $\phi$ が増加すると両ブ ロック間の親溶媒性の差が小さくなるため急激に減少し た. AS 膜の溶媒透過特性の支配因子は, 網目状高次構 造の網目サイズであることがわかった。

\section{参 考 文 献}

1) O. Smidsrod, A. Haug and B. Larsen, "The influence of $\mathrm{pH}$ on the rate of hydrolysis of acidic polysaccharides", Acta Chemica Scandinavica, Vol.20, No.4, pp.1026-1034 (1966).

2) A. Haug, S. Myklestad, B. Larsen and O. Smidsrod, "Correlation between chemical structure and physical properties of alginates”, Acta Chemica Scandinavica, Vol.21, No.3, pp.768-778 (1967).

3 ) B. Larsen, O. Smidsrod, A. Haug and T. Painter, "Determination by a kinetic method of the nearest-neighbour frequencies in a fragment of alginic acid", Acta Chemica Scandinavica, Vol.23, No.7, pp.2375-2388 (1969).

$4)$ H. Thiele, W. Jorachky, K. Plohnke, A. Wiechen, R. Wolf and A. Wollmer, "Prinzip einer strukturbildung ionen ordnen fadenmoleküle”, Kolloid-Zeitschrift \& Zeitschrift für Polymere, Vol.197, No.1-2, pp.26-35 (1964).

5 ) M. Rinaudo, "Main properties and current applications of some polysaccharides as biomaterials", Polymer International, Vol.57, No.3, pp.397-430 (2008)

$6)$ Y. Kasai, A. Akahira, S. Kakuta, A. Abudula, K. Urayama and T. Takigawa, "Preparation and electrochemical Properties of Alginate Sulfate Electrolyte Membranes", Kobunshi Ronbunshu, Vol.65, No.4, pp.295-300 (2008).

7 ) C. K. Yeom, J. G. Jegal and K. H. Lee, "Characterization of relaxation phenomena and permeation behaviors in sodium alginate membrane during pervaporation separation of ethanol-water mixture”, Journal of Applied Polymer Science, Vol.62, No.10, pp.1561-1576 (1996)

8 ) U. S. Toti and T. M. Aminabhavi, "Different viscosity grade sodium alginate and modified sodium alginate membranes in pervaporation separation of water + acetic acid and water + 
isopropanol mixtures”, Journal of Membrane Science, Vol.228, No.2, pp.199-208 (2004).

9 ) Y. Shi, X. Wang and G. Chen, "Pervaporation characteristics and solution-diffusion behaviors through sodium alginate dense membrane”, Journal of Applied Polymer Science, Vol.61, No.8, pp.1387-1394 (1996).

10) A. Mochizuki, S. Amiya, Y. Sato, H. Ogawara and S. Yamashita, "Pervaporation separation of water/ethanol mixtures through polysaccharide membranes. IV. The relationships between the permselectivity of alginic acid membrane and its solid state structure”, Journal of Applied Polymer Science, Vol.40, No.3-4, pp.385-400 (1990).

11) T. Uragami and M. Saito, "Studies on syntheses and permeabilities of special polymer membranes. 68 . Analysis of permeation and separation characteristics and new technique for separation of aqueous alcoholic solutions through alginic acid membranes”, Separation Science and Technology, Vol.24, No.7-8, pp.541-554 (1989).

12) D. Mihai, G. Mocanu and A. Carpov, "Chemical reactions on polysaccharides. I. Pullulan sulfation”, European Polymer Journal, Vol.37, No.3, pp.541-546 (2001).
13) K. I. Draget, G. Skjak-Braek and O. Smidsrod, "Alginic acid gels : the effect of alginate chemical composition and molecular weight”, Carbohydrate Polymers, Vol.25, No.1, pp.31-38 (1994).

14) A. Ikeda, A. Takemura and H. Ono, "Preparation of lowmolecular weight alginic acid by acid hydrolysis", Carbohydrate Polymers, Vol.42, No.4, pp.421-425 (2000).

15) K. I. Draget, G. Skjak-Braek, B. E. Christensen, O. Gaserod and O. Smidsrod, "Swelling and partial solubilization of alginic acid gel beads in acidic buffer", Carbohydrate Polymers Vol.29, No.3, pp.209-215 (1996).

16) S. Nosaka, T. Ishida, K. Urayama and T. Takiwgawa, "Steady flow properties of a mixed solvent through a poly ( $\mathrm{N}$-isopropylacrylamide) gel”, Journal of Membrane Science, Vol.305, No.1-2, pp.325-331 (2007).

17) Y. Hirokawa, H. Jinnai, Y. Nishikawa, T. Okamoto and T. Hashimoto, "Direct observation of internal structures in poly(N-isopropylacrylamide) chemical gels”, Macromolecules, Vol.32, No.21, pp.7093-7099 (1999). 